\title{
POLITICAL AGITATION FOR FOREST CONSERVATION: VICTORIA, 1860-1960
}

STEPHEN LEGG

School of Philosophical, Historical and International Studies,

Monash University

\section{Abstract}

Victoria has a remarkably long history of agitation to gain political influence over forest management. With much of the region being forested on the eve of European colonisation in the mid-1830s, more than a century ensued of government support for forest clearance and the exploitation of forest products. From the early 1860s, however, various interest groups engaged in lobbying, petitions, public protest meetings, strategy planning conferences, press campaigns, circularising, and deputations to pressure Victoria's parliament during, and between, elections to conserve the forests. By international standards, these campaigns came relatively early, were diverse, persistent and well coordinated, but at least initially met with little success. Furthermore, as was the case throughout Australasia and much of the British Empire, most of Victoria's forests were publicly owned and managed (as Crown land reserves) for various public purposes,${ }^{1}$ but were predominantly exploited by private industry.

The role of key parliamentarians, public servants and institutions governing the development and application of forest legislation is gradually being detailed. ${ }^{2}$ However, there is a need to consolidate and develop the varied research that has been done on the contribution of the various non-government organisations and individuals. In particular, the influence of the popular press and the mining lobby has hitherto been seriously understated, while some modern environmentalists have tended to undervalue the long history of struggle, and dismiss its utilitarian emphasis.

\footnotetext{
1 Ray Wright, Space and the Public Interest in Victoria, 1836-84 (Melbourne: Oxford University Press, 1989).

2 Joseph Powell, Environmental Management in Australia (Melbourne: Oxford University Press, 1976); Frank Moulds, The Dynamic Forest: A History of Forestry and Forest Industries in Victoria (Melbourne: Lynedoch, 1991); Leslie Carron, A History of Forestry in Australia (Canberra: Australian National University Press, 1985); Stephen M. Legg, 'Debating Forestry - An Historical Geography of Forestry Policy in Victoria and South Australia, 1870-1939' (PhD diss., Monash University, 1995); Wright, The Bureaucrats' Domain; Angela Taylor, A Forester's Log: The Story of John La Gerche and the Ballarat-Creswick State Forest 1882-1897 (Melbourne: Melbourne University Press, 1998); Brian V. Doolan, 'Institutional Continuity and Change in Victoria's Forests and Parks' (MA diss., Monash University, 2015). These references document many of the conservation-minded politicians and bureaucrats who campaigned to save the forests, but who remain largely beyond the scope of the present paper.
} 
Using a broadly chronological narrative, this paper outlines the purpose, methods, organisation and impact of lobbyists involved in three landmark disputes over forest conservation. It traces changing attitudes to, and major policies governing, Victoria's forests, focusing particularly on perceptions of the role of public forestry. In so doing, it demonstrates the length, breadth and complexity of the forest conservation campaigns.

Keywords: forest conservation, political agitation, lobbying, gold-mining, the press, Victoria

\section{The press: An overview}

A comprehensive analysis of the press lies beyond the scope of this paper, but a few strategic observations are useful to indicate the nature, timing and intensity of press coverage during the study period, as well as to contextualise the role of the press in lobbying for forest conservation. Figure 1 shows the historical distribution of the 1,565 items dealing directly with forest conservation published between 1863 and 1956, revealed by a survey of 73 newspapers from 59 communities across Victoria. ${ }^{3}$ Press coverage grew from the early 1860s due largely to debate on the need to conserve timber and firewood for consumption by the gold-mining industry and pressure from mining interests (see 'The mining lobby, 1865-1907' section below). This was followed by half a dozen notable episodes, mainly coinciding with parliamentary raids on forest reserves for settlement and failed parliamentary forestry bills, before peaking in 1887 with massive deforestation in the Otway Ranges, and around the general election in 1889 at which forest conservation was a minor but persistent issue. Apart from calls to secure mining timber supplies, largely through the introduction of government-run 'scientific forestry' on Crown land reserves, there was considerable contention about the need to preserve native forests and expand plantations to ensure the supposed climatic benefits of forests. The climatic value of forests received much attention during, but was not exclusively limited to, periods of drought (especially in the mid-1880s and the so-called Federation drought 1896-1902). ${ }^{4}$ Much of the conservation material presented was initially sourced from overseas and supported by the progressive local press. The sharp

\footnotetext{
3 Survey results from search string 'forest + conservation' in Trove historic newspaper digital database of 73 of Victoria's most prominent and long-lived metropolitan and provincial newspapers, 1840-1957. The survey comprised 12 titles from metropolitan Melbourne, 15 from outer Melbourne suburbs, five from provincial cities (Ballarat, Bendigo and Geelong) and 41 from small country towns.

4 Stephen Legg, 'Debating the Climatological Role of Forests in Australia, 1827-1949: A Survey of the Popular Press', in Climate, Science, and Colonization: Histories from Australia and New Zealand, ed. James Beattie, Emily O'Gorman, and Matthew Henry (New York: Palgrave Macmillan, 2014), 119-36.
} 
decline in coverage in the 1890s owed much to the financial crisis and ensuing economic depression of the early 1890s as well as falling gold yields, both factors contributing to reduced timber consumption and temporarily less pressure on the forests. Other factors suppressing calls for forest conservation in the early 1890s included reduced forest clearance for agriculture, a dramatic decline in timber and firewood use by the Victorian Railways (for sleepers and firing locomotives respectively), and increasingly effective political organisation by rural interests.

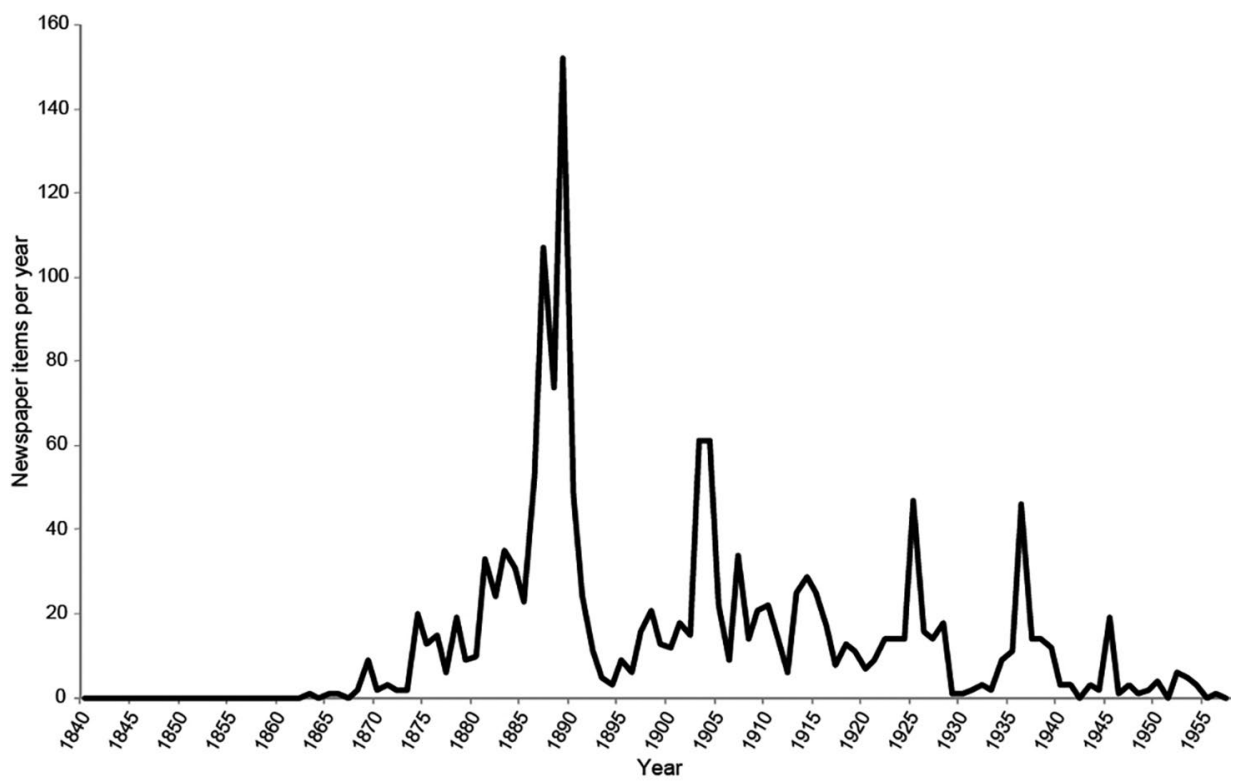

Figure 1: Press coverage of forest conservation issues in Victoria, 1840-1957.

Source: Analysis of all reports dealing explicitly with forest conservation published in 73 Victorian newspapers, 1840-1957.

Press coverage revived during the late 1890s as agitation grew for significant forest reforms. These were forthcoming with the establishment of a Royal Commission on Forests in 1897 and expansion of forest reserves under the 1898 Land Act. The commission produced 14 separate reports before closing in 1904, a year that saw intense public lobbying over forest exchanges between the Lands and Forests Departments. Conservationists' hopes were soon dashed by the popular clamour for 'Closer Settlement' through the excision (subdivision and sale) of Crown lands, rising fears that existing forest reserves harboured vermin and noxious weeds, the growing scientific criticism of the popular belief that forests attracted rain, and the increasing success of irrigation in agricultural regions. Nevertheless, the 1907 and 1918 Forests Acts both resulted in the establishment of more independent and professional forest services in Victoria as well as ushering in an era of relative institutional stability in public 
forests management. ${ }^{5}$ The remaining peaks in press coverage were separated by a lull brought on by the exigencies of the Great Depression, World War II, and the postwar housing boom respectively (the first seriously reducing timber consumption and the latter two involving huge drains on timber supplies). The three intervening peaks related to intense struggles over the mountain forests between conservationists, water managers and the Forests Commission of Victoria (FCV) on the one side and agricultural and grazing interests on the other in the 1920s (see 'The Otway Forest dispute, 1923-25' section below), a split between conservationists and the Forests Commission over timber extraction on selected sites (see 'The Cumberland Valley dispute, 1923-43' section below), and concerted campaigns to 'Save the Forests' in the late 1930s, culminating in 1944-45 (see 'Diversifying Values, 1936-55' section below).

The popular press in Victoria, and elsewhere in Australia, was the largest single forum for information on forest conservation issues during the study period, especially before the end of World War II after which there was a notable decline in political activism by the press on most issues until the late 1960s. Forest conservation was widely canvassed by the 'progressive' press across Victoria during the study period, with support across the political spectrum from the conservative to the more liberal press, and with Labor party supporters particularly active in the first half of the twentieth century. The Victorian press was instrumental in popularising broader conservation-related concepts such as 'Forest Influences on Climate' (from the late 1850s), the 'Balance of Nature' (from at least 1861), an 'Ecological Awareness' (indirectly from at least the 1880s and directly from 1906), a 'Forest Conscience' (from 1912), and the importance of forest habitat to nature conservation (adding to the earlier species emphasis particularly from the 1920s). As pressure for game preservation rose from the 1880 s, demands for forests as wildlife sanctuaries grew, and these calls gradually diversified during the following 70 years with campaigns for National Parks and wider recreational use of forests. ${ }^{6}$ Specialist 'natural history' and 'scientific' columns supported the growing interest in Nature, in which forests were seen to be increasingly important. Collectively, the press fuelled debate and positioned action with a regular and voluminous stream of summaries of relevant parliamentary debates and papers (the latter including departmental reports and committees of inquiry), deputations, election speeches, lobbyists' press releases and speeches, minutes from the local mining and forest boards as well

5 Doolan, 'Institutional Continuity', chap. 3.

6 Campaigns to preserve forests for wildlife habitat in Victoria became prominent from the 1920s: see Stephen Legg, 'Bunyips, battues and bears: Wildlife portrayed in the popular press, Victoria 1839-1948', in Conservation of Australia's Forest Fauna, ed. D. Lunney, 2nd ed. (Mosman: Royal Zoological Society of New South Wales, 2004), 150-74. 
as local municipal council meetings, public lectures from Melbourne University and learned societies (in science, forestry and agriculture), book reviews, and gleanings from disciplines including economics, science and natural history.

Initially, newspaper conservation campaigns focused mainly on colonial/state government affairs, with reporters assiduously analysing parliamentary bills related to forest management and proposing their own legislation. Editors regularly attacked ministerial raids on the forests for settlement, usually from Lands and Agriculture ministers, lamented the influence of vested interests in parliament, and railed against inadequate controls over timber-getting, ringbarking and bushfire. In mining districts there was strong support for local control of forest management to stave off political pork-barrelling from afar. Up to the late 1930s, editors often proactively canvassed what was seen as examples of progressive forest management, the rationale during an era long dominated by agricultural clearance being that forests could only be saved from destruction if their utilitarian value was assured. Arboriculture for the lightly wooded regions was often promoted during the late nineteenth century to ameliorate climate and increase local wood supply. The importance of forests in water supply became prominent from the 1880s with the spread of irrigation, and from the 1920s with increasing efforts to control erosion in forested watersheds. Local government management of forests, such as municipal council by-laws protecting forests, the control of roadside trees, and regulation of timber cartage on local roads, were widely canvassed. Although the provincial press often 'boosted' the timber industry and agricultural clearance for local economic development, attempts by local councils and councillors to conserve forests were also occasionally promoted. Federal government policies (from Federation in 1901) received less attention in part because forest control was largely assigned to the states under the Constitution, and also because some Federal policies met with press resistance, e.g. over plans to relocate state forestry schools to the Federal capital, Canberra, early in the twentieth century, and persistently with tariff policies influencing the cost of timber imports.

For at least a century after the earliest campaigns were mounted in the 1860s, the press was exploited effectively by the various forest conservation lobby groups with the strategic use of press releases honed to an art form, and with letters to the editor a significant outlet for public opinion. Quite apart from the unprecedented forum offered by the newspapers, press owners and editors were among Victoria's most powerful conservation lobbyists. At least 16 Victorian newspapers consistently lobbied on the issue, and in many cases maintained persistent editorial lines that long outlived the activists and campaigns they supported. Dozens of other newspapers regularly published pro-conservation articles, even though their editorials were silent on the issue. Even in the most densely forested regions, where forests appeared an obstacle to agricultural 
development and the timber industry was often exploitive, a few individual newspapers and editors were prominent activists. ${ }^{7}$ Much of the press lobbying emanated from the Melbourne metropolitan region and especially from the central and north-eastern goldfields - and it is to the goldfields agitation that I now turn.

\section{The mining lobby, 1865-1907}

Paradoxically, gold-mining was one of Victoria's major agents of forest degradation and yet also an industry that led the early public struggle for forest conservation. ${ }^{8}$ This leadership was in pursuit of self-interest, and arose because no other interest group was powerful enough to promote forest reservation against the other lobby groups. For more than 40 years from the mid-1860s, the organised mining interests and the parliamentary 'mining members' who represented the mining electorates maintained a surprisingly consistent, generally unified and ultimately effective political agitation. This was despite jealousies between different mining districts, the fickle nature of factionalism in the Victorian parliament, and the fact that the mining members rarely comprised more than a third of parliamentary seats. Mining interests fought to establish a system of well-regulated state forest reserves to stave off the depredations of settlers and timber getters. They also forced the establishment of a number of committees of inquiry into forest management (especially the State Forests Inquiry 1865, Foreign Industries and Forests Royal Commission 1871, and the Forests Royal Commission 1897-1904). ${ }^{9}$ They lobbied for effective regulation, shaped the introduction of more than a dozen forest bills, and with their allies succeeded in 1907 in having the first substantial Forests Act passed in the Victorian parliament. Although their political influence declined dramatically due to the collapse of gold yields from 1905, they managed to force the concession of a joint ministry of Mines and Forests (1904-09) and ensured that eight of the next 10 Mines ministers before November 1924 held the Forests portfolio simultaneously. Without in any way understating the widespread destruction wrought on forests by the mining industry in Victoria, their political

\footnotetext{
7 Stephen Legg, 'Forest Conservation and the Gippsland Press: A brief editorial survey, 1855-1962', in Earth and Industry: Stories from Gippsland, ed. E. Eklund and J. Fenley (Melbourne: Monash University Publishing, 2015), 20-36.

8 An overview is provided here as I have detailed some of these complex campaigns elsewhere: Stephen M. Legg, 'Mining and the Timber Question - early forest conservation movements in Victoria before 1918,' Asia-Pacific Economic and Business History Conference, University of Melbourne, February 2008; 'Passionate Advocates', in Australia's Ever-Changing Forests VI, ed. B.J. Stubbs, J. Lennon, A. Specht, A., and J. Taylor (Canberra: Australian Forest History Society, 2012), 187-200.

9 Mining interests also ensured the Royal Commission into Gold Mining 1889-91 dealt extensively with the shortcomings of forest management.
} 
agitation to conserve forests was remarkable by international standards, and was arguably one of the earliest, longest, and most highly organised industrial forest conservation campaigns in the world. ${ }^{10}$

The agitation was led by representatives of the large deep lead and quartz mining companies. They dominated the industry from the late 1860s after the small individualistic surface miners had worked out the easily accessible alluvium. Their concern was to secure massive, cheap, permanent supplies of mining timber and laths for the shafts along with firewood to power the steam engines. The latter drove the quartz batteries, winched the mining cages and pumped water from the mines. But wood prices escalated as the supplies dwindled and were carted from increasingly distant forests. As well as the continued assault on the forests by the miners, local timber was depleted by forest clearance from many quarters. Prospective settlers clamoured for forest lands for agricultural purposes and to speculate on rising timber prices; graziers seasonally lit fires to promote fresh grass and their cattle depleted seedlings. And there was a wide range of destruction from poorly regulated timber getters, sleeper hewers, firewood collectors, and timber millers. The Amalgamated Miners' Association (AMA) became increasingly concerned to join the agitation from the 1880 s as the miners' jobs became marginalised by rising timber prices and their lives were threatened by the deteriorating quality of pit props. ${ }^{11}$ Parliament was lobbied on the matter by the various regional mine owners', managers' and directors' associations, the local stock exchanges, shareholders' associations, the miners' unions, the Chambers of Mines, and especially the mining boards who coordinated the agitation. There was strong support from many of the goldfields' municipal councils. ${ }^{12}$ The popular press in Melbourne and on the goldfields notably from Ballarat, Bendigo and Maryborough (see Map 1) were particularly active in publishing international and local concerns over forest conservation.

10 Whereas the Victorian gold-mining industry avoided planting its own timber supplies and relied instead on agitating for public forestry, a few corporations elsewhere established their own forest plantations. These included the coal Mining Company of Ireland's pit-prop plantation at Glendalough from 1857 (www.mindat.org/article.php/368/A+History+of+Glendalough), experimental plantations from the early 1870 s by various US railroad companies (John Ise, The United States Forest Policy (New Haven, CT: Yale University Press, 1920)), and the Gold Mining Estates' mining timber plantations on the Transvaal from 1903 (Grant Wardell-Johnson and Michael Calver, 'Toward sustainable management: Southern Africa's Afromontane, and Western Australia's jarrah, forests', in A Forest Consciousness: Proceedings of the Sixth National Conference of the Australian Forest History Society Inc., ed. M. Calver et al. (Rotterdam: Millpress, 2005)). The (imperial) Nuremburg Reichswald was originally established in the fourteenth century after agitation from merchants concerned at fuelwood shortages that endangered the local metal industry (Otto Kandler, 'Historical Declines and Dieback of Central European Forests and Present Conditions', Environmental Toxicology and Chemistry 11 (1993): 1077-1093).

11 As prices rose, mines increased the spacing of new props and replaced decayed timber less frequently. Mine dividends and employment fell by about a third each during the 1880s: Legg, 'Debating Forestry', 145-6.

12 Support from some of the mining boards and municipal councils in densely forested areas such as Gippsland and the North-East was sometimes lacking. 


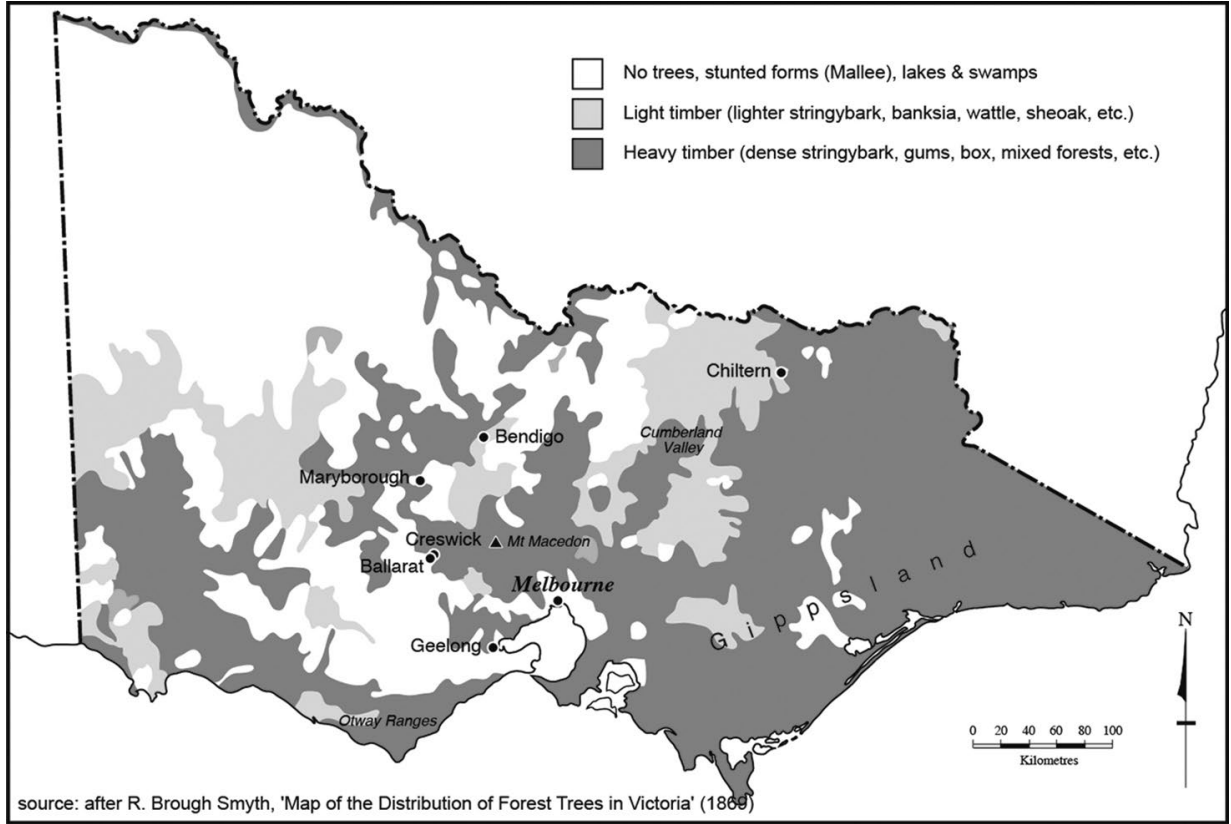

Map 1: Victoria's forests, 1869.

Source: After R. Brough Smyth, 'Map of the Distribution of Forest Trees in Victoria' (1869).

The mining boards were alarmed at the land rush into the goldfields forests resulting from section 42 of the 1865 Land Act (and subsequent 'selection before survey' settlement legislation). The campaign's principal coordinator was Ballarat Mining Board secretary James Bickett until his retirement at age 87 in 1905. The mining boards successfully lobbied for the establishment of permanent state forests in 1865-66 and were instrumental in securing large portions of the main mining timber-supply forest at Bullarook, near Ballarat, in 1869. Forest reservation increased across Victoria, but many reserves remained subject to ministerial revocation without parliamentary approval. Ostensibly, wishing to better control the pork-barrelling that regularly saw Lands and Agriculture ministers agree to the alienation for settlement purposes of timber reserves and state forests, the mining interests fought successfully from 1872 for the establishment of local forest boards. Hamstrung by their inability to raise sufficient revenue and burdened by petty squabbling among the 13 local forest boards over control of neighbouring forests, the local boards were soon dismantled although, in the interim, they were coordinated by a newly established Central Forest Board (1874-88), which was the administrative precursor of the later Forests Branch. The Forests Branch was itself starved of funding and for most of its 19-year history was shuffled between the powerful Lands and Agriculture departments whose officials remained largely inimical to forest conservation. The mining interests campaigned to have the branch 
controlled by the Mines department, which was more likely to align with their sectional interests, and this was achieved briefly in the early 1890s and then indirectly during most of the period from 1905 to 1918.

The lobbyists employed press campaigns, petitions, notices of motion in parliament and the stacking of committees of inquiry by the 'mining members', as well as increasingly powerful and widely represented deputations to the relevant ministers. As the forests were depleted, the agitation became consecutively dominated by the central goldfields around Ballarat, Maryborough and Bendigo, then the north-east around Chiltern, and finally Melbournethe last through the central Chamber of Mines and representatives of some of the Gippsland mines. ${ }^{13}$ Figure 2 shows the timing of these deputations and the location of participating members during the study period. From the late 1880s, the rising price of mining timber from the continued depredations on the forests made the situation more urgent. Thereafter the degree of coordination, sophistication and breadth of interest group alignments increased markedly. ${ }^{14}$ The lobbyists included once peripheral groups such as the apiarists, once competitor groups such as the timber millers and merchants, and increasing involvement from the miners' unions.

The alienation of forests for settlement at Mount Macedon in 1879 and in the Otway Ranges in 1887 caused a furore in the parliament and press. ${ }^{15}$ The mining lobby were particularly alarmed at the loss of important mining timber supplies and more especially at the minister's flagrant rejection of the expert advice regarding the inevitable abandonment of these lands once the forests had been destroyed. The climatic, hydrological and silvicultural losses from the clearance were concerning especially as it was feared that many of those selecting Crown lands were merely speculators ('land jobbers'). ${ }^{16}$ The Land Acts required bona fide selectors to annually 'improve' their land by clearing with axe and fire, and while many settlers simply acquired the land to sell off the timber, the forest was destroyed just the same.

13 The latter included the state coal mine at Wonthaggi after the Great War.

14 It is likely that the mining interests' campaign would have been largely dismantled had the railways been able to meet increasing demands for mining timber either by extension to new supply forests or lower freight charges, or if there had been adequate coal supplies to substitute for firewood.

15 Much to the delight of his conservative contemporaries, firebrand Melbourne Age editor David Syme's campaign against 'political influence' was compromised by his alleged pressure, via parliamentarian Alfred Deakin, to ensure Lands Minister Francis Longmore maintained the forest reserves surrounding Syme's Mount Macedon residence (Gippsland Times, 18 June 1879).

16 Settlers obtaining Crown lands under a series of land settlement laws between 1860 and the late 1890s were dubbed 'selectors' until they met all of the licence and lease requirements under the relevant Selection Act. 


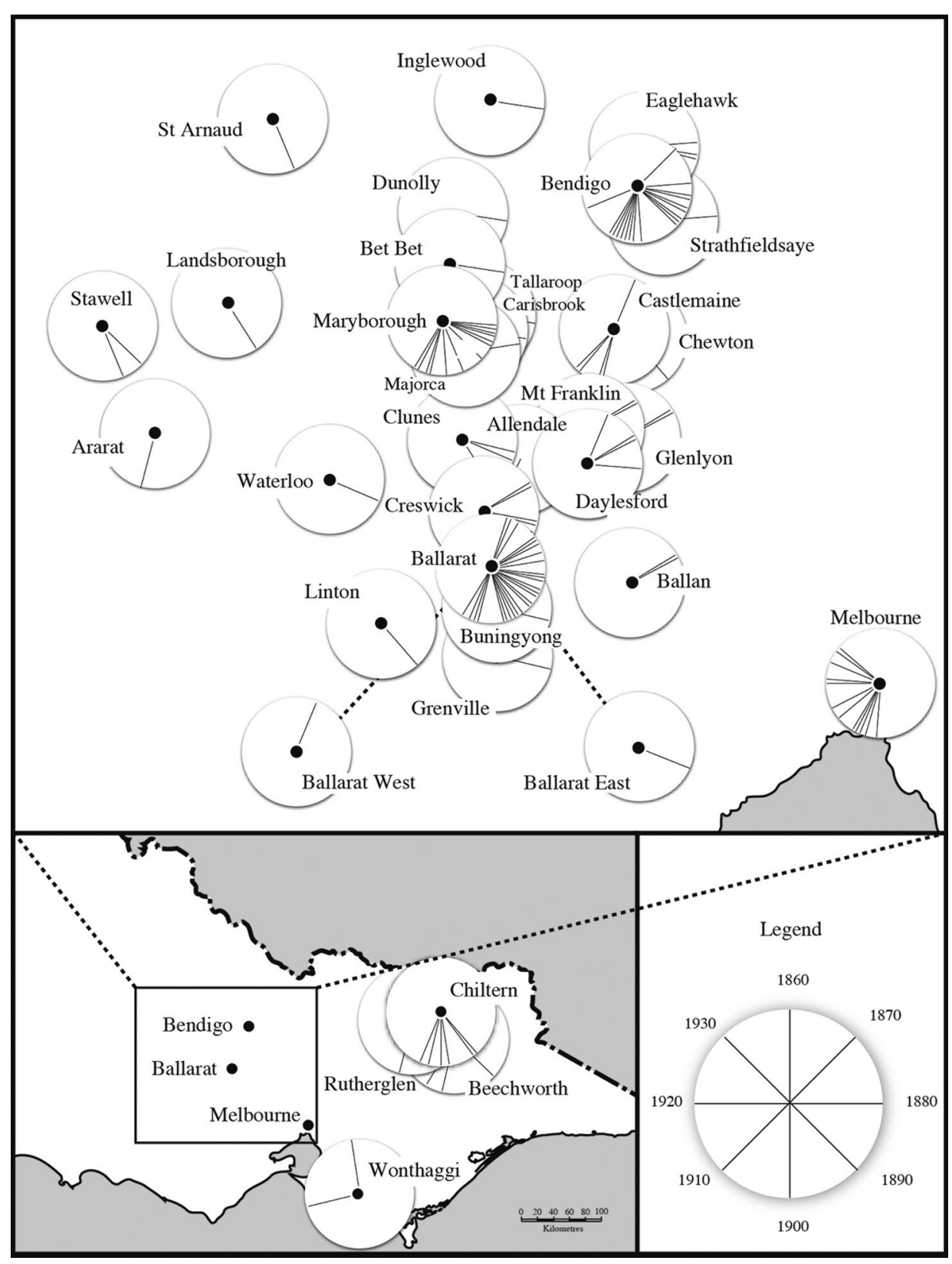

Figure 2: Mining timber deputations, 1864-1938.

Source: Analysis of reports of mining timber deputations published in 73 Victorian newspapers, 1840-1957.

From August 1888, the mining interests were joined in Bendigo by the Northern District Forests Conservation League (NDFCL). The group was a loose coalition of mine owners, municipal and commercial interests. Parliamentary mining 
member James McColl and Bendigo timber merchant and Mayor Cr J. B. Hoskins as well as Mayor $\mathrm{Cr}$ J. Cohn were among the most prominent membersthe NDFCL chair always being the incumbent Mayor of Sandhurst. The NDFCL regularly canvassed support from municipal councils throughout Victoria. They circularised parliamentarians requesting them to publicly pledge their position on forest conservation, promoted their own forests bill, lobbied and petitioned the minister, sent deputations, and strongly canvassed conservation in the 1889 general election. ${ }^{17}$ About a quarter of parliamentary candidates around Ballarat, Maryborough and Creswick showed some concern at forest destruction but there was little in the way of a consistent or comprehensive solution to the problem. The NDFCL forced more unified support for forest conservation among candidates in the northern electorates around Bendigo, but the government's promised forest bill was never delivered and the League was disbanded after June $1890 .{ }^{18}$ Mining interests managed to secure a massive increase in forest reserves from the 1898 Land Act, thanks mainly to the recommendations of a comprehensive 1897 report by Surveyor General S. K. Vickery and Chief Inspector of Forests J. Blackburne, as well as the efforts of the Royal Commission on Forests established two months later. James Blackburne was later embittered by his treatment by the government and frustrated at the general lack of reform in forestry management. He was also critical of the government's dealings with his mentor, Chief Conservator George Perrin, whose untimely death in 1901 gave Blackburne hope to lead the Forests department. ${ }^{19}$ Perrin's departmental reports recognised the importance of mining but he was often in dispute with the mining lobby over their resistance to both harsher forest regulations and the introduction of royalties. One of Perrin's last reports protested that a proposal to amalgamate the Forests branch with the Mining department would see conservation 'subservient to the timber requirements of the mining districts' ${ }^{20}$ Perrin was alternately allied with, and an obstacle to, the mining interests.

\footnotetext{
17 The NDFCL was predated by a dozen years by a few US Forestry Associations established from 1875. The US Associations had wider aims that encompassed arboriculture and climate amelioration compared to the mining-timber-oriented NDFCL, and despite its title the latter cannot strictly be regarded as 'the first conservation group in the world' (Tim Bonyhady, The Colonial Earth (Melbourne: Miegunyah Press, 2000), 182). Even earlier political agitation for forest conservation came from Forestry Associations formed in Switzerland and Austria in the 1840s, and the Scottish Arboricultural Society established in 1854.

18 See electoral speeches and political platforms by candidates and goldfields organisations for the March 1889 election in the Ballarat Star, Ballarat Courier, Bendigo Advertiser, Bendigonian, Creswick Advertiser, and Maryborough Advertiser, passim.

19 Blackburne clashed with Lands ministers throughout his career, notably as a young district forester resisting alienation of the Bullarook Forest (Argus, 10 February 1881) and later as Forest Inspector when his reports on the Fumina Lands were ignored in 1903 (Legg, 'Passionate Advocates', 196). His grievances included Cabinet's failure to ratify the Public Service Board's recommendation that he be appointed acting Conservator in 1901, the abolition of the position of Chief Forests Inspector 'for cost cutting reasons' in 1902, and government bungling of his pension thereafter (Bendigo Advertiser, 5 June 1901, 1 March 1902).

20 Bendigo Advertiser, 19 January 1891.
} 
In 1903, the Forests branch was shifted yet again between the Lands and Agriculture departments, its Acting Conservator was removed, and it was unable to combat the government's release for agriculture of the densely forested and often inaccessible 'Blue Block' lands. In that year, the recently retired Blackburne was appointed secretary to the short-lived but powerful National Forests Protection League (NFPL). Initially based on Maryborough mining interests, it soon attracted groups from across all of the goldfields as well as an unprecedented alignment of once conflicting interests from throughout Victoria and a couple from other states. A Bendigo branch of the NFPL was formed by the same Councillor Hoskins who had led the NDFCL. The NFPL was mainly but not exclusively utilitarian in its forest values, and there was a wellconsidered strategy to include the hydrological significance of forests to placate agricultural interests, which were increasingly concerned with irrigation and erosion. The League proved highly effective in repositioning the debate at a time when gold-mining was on the verge of economic collapse. The executive committee's strategy included well-attended protest meetings, public lectures, conferences, and direct lobbying of relevant bureaucrats and parliamentarians, ministerial deputations, pamphleteering, regular contact with similar interest groups, and an intensive press campaign. The NFPL pressured groups as diverse as the provincial Stock Exchanges and the Amalgamated Miners' Union on the impact of deforestation on the loss of profits and jobs respectively. The AMA's annual conferences regularly canvassed the mining timber question between 1904 and 1907.

Nevertheless, in 1904 the NFPL was effectively bought off by the government. The Premier undermined support of some of the key mining members affiliated with it, reinstated the embittered Blackburne as Inspector of Forests in a reorganised Forests department, and as a precursor to the promised forest bill, instituted a wide-ranging field survey of the forests (by forester Arthur Tatham). ${ }^{21}$ Despite the promise, Premier Thomas Bent's Government was returned in a landslide mainly on a platform of expanded Closer Settlement, and settlement interests delayed the bill for another three years. In desperation, the Bendigo Mining Board mooted the formation of a 'United States' Forest Protection League' to bolster the flagging agitation early in 1904, but nothing came of the move. The NFPL's Maryborough and Bendigo branches were active through 1905, but by 1906 the League was only referred to as the Maryborough Forest Protection League and seems to have been disbanded soon after.

21 Tatham had extensive experience as a forester in Ceylon, and his was the third report invited by Victorian governments on forestry by foresters from the British Forest Services in the sub-Continentthe previous two were from Indian foresters Frederick d'Vincent in 1887 and Bertholdt Ribbentrop in 1896. All three reports were scathing of 'political influence' and the neglect of forest conservation. Ironically, Blackburne snidely reflected on Tatham as 'a so-called expert ... who knew little or nothing of Victoria's forests' (Bendigo Advertiser, 25 May 1904). Tatham's report brought about little fundamental change. 
The mining interests were often joined in their forest conservation campaigns by the powerful and eclectic 'friendly society', the Australian Natives Association (ANA), formed in 1871. Although far from having a single focus, the ANA became the largest interest group to support forest conservation in Victoria during the study period. ${ }^{22}$ Its size and organisation made it a powerful political and cultural force. Various local branches began promoting forest conservation among their wide-ranging civic interests in 1885 and especially from the 1889 state election. Formalisation of the issue as an ANA policy priority came at the 1903 Annual Conference thanks largely to pressure from mining interests, including the NFPL..$^{23}$ The ANA organised parliamentary deputations calling for improved forest management in each of the three years between 1905 and 1907, and this was only the beginning of a lengthy campaign over the next 40 years.

The first comprehensive forest bill to be passed, the 1907 Forests Act, established an independent Forests department under its own Minister of Forests but in practice this portfolio was held jointly with Mines. ${ }^{24}$ Settlement interests had insisted on a five-year period within which exchanges of land could be made between the Forests and Lands departments, in lieu of any outright loss of forest land. But the remaining parliamentary mining members had little power to bargain in a period when 'land hunger' was renewed, the gold-mining industry had collapsed and a renewed attack on the mining boards saw them eventually dismantled in 1914. Between 1908 and 1910, ANA campaigns to improve management of Victoria's mountain catchment forests were ignored by government largely due to pressure from grazing and timber interests.

22 By 1891 the ANA had grown to 8,000 members in 129 branches in Victoria, by 1941 there were 46,000 members in 330 branches, and 30 years later the number of branches had only increased by nine but there were then 83,000 members (J. E. Menadue, A centenary history of the Australian Natives' Association, 1871-1971 (Melbourne: Horticultural Press, 1971), 26-31).

23 ANA delegate for the mining district of Rushworth, W. F. 'Mac' McNamara was instrumental in having the forest question placed on the ANA's 'national' policy platform in 1903. He worked for the Forests and Lands departments as a young man and agitated for forest conservation for over 20 years. He rose to be ANA President. McNamara led many deputations and organised campaigns on forest management, including agitation over what became the 1907 Forests Act, mountain forests in 1910 and the struggle for an independent Forests Commission 1916-18 (Bendigonian, 21 February 1918). He was also a founding member of the Australian Forests League in 1912. Another highly influential ANA member was 'mining member' parliamentarian Sir Alexander Peacock who was Forests Minister in the early 1920s and three-times Premier throughout his long parliamentary career (1889-1933). As a mine manager, Peacock had been heavily involved in mining timber agitation in the 1880s, and remained connected with mine management most of his adult life. 24 Previous draft bills were defeated in 1879, 1881, 1887, and 1892 (Doolan, 'Institutional Continuity', 115). 


\section{Reducing insularity, 1907-22}

To fill the power vacuum left by the decline of the mining lobby, and partly to realise the potential of the ANA and the labour unions, conservationists began to rely on a more national perspective. Frustrated at the lack of progress in forestry and broader forest conservation, several foresters and scientists formed the Australian Forest League (AFL) in 1912. The League was proposed at the 1911 Interstate Forestry Conference in Sydney and developed by the Botany section of the Australian Association for the Advancement of Science. ${ }^{25}$ The Victorian Branch was to remain the most powerful and active of the six state branches, a position it maintained over the next 34 years. Fittingly, it was Victoria's leading mining member, Maryborough MLA Alfred Outtrim, who publicly proposed the Victorian AFL branch. ${ }^{26}$ However, by 1913 wood supply for the mines was becoming adequate for the first time in decades, thanks to the combination of three factors: the increasing substitution of wood by steaming coal on the northern goldfields by 1904, the dramatic fall in demand for mining fuel and timber from 1905, and increased forest planting by the Forests department from 1908.

The ANA was now joined by organisations led by a new breed of professional foresters and academics with important links to increasingly activist groups such as the Field Naturalists' Club of Victoria (FNCV), formed in 1881. The AFL's inaugural President, Melbourne University Botany chair and Government Botanist Professor Alfred Ewart, was a member of both the FNCV and the AFL, as were a number of others, including prominent Forests department staff member A. D. Hardy and the second president of the AFL, Russell Grimwade. The FNCV periodically lobbied for forest preservation from 1889, and by 1903 had joined Blackburne's NFPL as a corporate member.

The FNCV had strong links through its membership to Melbourne University and the Royal Society of Victoria, as well as natural history groups such as the Royal Ornithologists' Union. By 1907 the FNCV journal, The Victorian Naturalist, regularly canvassed the Forests departments' reports supplemented by lectures and papers from forest technician A. D. Hardy, Forestry School Head T. S. Hart, FCV Chairman Owen Jones and forester C. M. Ewart. ${ }^{27}$ The AFL's journal, The Gum Tree, was established in 1917 to more directly lobby on forestry matters. It reciprocated by publicising the FNCV activities, and the

\footnotetext{
25 The Gum Tree (vol. 1, no. 1, March 1917, 5).

26 A mine manager early in his career, Outtrim was Minister of Forests in 1892, one of the Forests Royal Commissioners from 1897, had initiated what became the NFPL in 1903, and was later appointed Minister of Mines (and Forests).

27 Other passionate forest conservationists among FNCV members included biologist Professor Baldwin Spencer, historian Charles Daley and engineer/historian A. S. Kenyon.
} 
two bodies were closely aligned on values - although the AFL was more overtly utilitarian in its view of the forests, and the FNCV was particularly focused on its political agitation to create more National Parks. Both groups regularly railed at the excesses of forest destruction around the state. The AFL, however, was periodically challenged by its strong support for and reciprocal links with the Forests department and after 1918 its successor the FCV. ${ }^{28}$ Nevertheless, there was no financial support from government for any of the forest lobbies. ${ }^{29}$

From 1909, leading timber manufacturers and workers' groups pressured governments for the substitution of timber imports with native timbers. They also agitated for the better utilisation of Victoria's hardwood forests through the establishment of a technically advanced state-owned seasoning works and sawmill. But governments reacted slowly. During the Great War, and especially at the 1914 and 1917 elections, the ANA, AFL and FNCV vigorously lobbied to eliminate political interference in forest management, establish adequate funding, reduce waste, expand softwood production, and address growing international concern at an impending 'timber famine'. The Victorian Chamber of Commerce, the Royal Victorian Institute of Architects (RVIA), the Apiarists' Association and various paper manufacturing interests joined the campaign. Valued support came from the ex-forester Governor-General Sir Ronald MunroFerguson, and a strengthened forests platform from the Labor Party. Wartime timber shortages and the prospect of employing returned soldiers in forestry work added urgency to the demands for an independent Forests Commission, but it was only by departing from the old departmental model that the increasingly technical operational requirements of a fully professional forest service could be met. Established in 1918, the FCV gained further legitimacy as interest in establishing an Empire Forestry movement peaked around 1920. ${ }^{30}$

However, only three years after the establishment of the FCV, settlement interests in the Victorian Government lobbied by the powerful Victorian Farmers' Union again renewed the call for forest alienation. Throughout the next two decades, bitter struggles ensued in parliament to limit the FCV's powers. ${ }^{31}$ A range of Commonwealth and Victorian initiatives to bring local land together with British 'men, money and markets' was established in the early 1920s, including

\footnotetext{
28 'The FCV looked to the League [for] support in its enterprises and to educate the public in the aims and ideals of forestry.' The Gum Tree (vol. 6, no. 17, March 1921, 3). The AFL's patron, Governor-General Sir Ronald Munro-Ferguson, represented Australia on the Empire Forestry Association after its formation in 1920.

29 Co-founder of the AFL, V. B. Trapp complained of the lack of financial support at the RVIA and AFL Timber Conference at the Melbourne Town Hall (Argus, 29 November 1916).

30 On timber famine see American Forestry Association, 'Proceedings of the American Forest Congress,' $\mathrm{H}$. M. Suter, Washington D.C., 1905; on the Empire Forestry movement see Joseph M. Powell, “'Dominion over Palm and Pine": the British Empire forestry conferences, 1920-1947', Journal of Historical Geography 33, no. 4 (October 2007): 852-77.

31 This complex period of political manoeuvring is described in Legg 'Debating Forestry', 263-313.
} 
the Million Farms Scheme, Group Settlement, and a Mountainous Lands clause specifically designed to tackle the densely forested hill country that had resisted earlier settlement attempts. ${ }^{32}$

\section{The Otway Forest dispute, 1923-25}

The Lands Minister stated in 1921 that he would no longer consult with the FCV over land settlement. The first test case came in November 1923 when he announced a proposal to throw open nearly 27,000 acres of Crown forests for farming in the densely forested Otway Ranges, ironically in an area surrounded by 90,000 acres of abandoned farmland from previous settlement attempts (Map 2). Political agitation to support the FCV's opposition to the scheme was swift. The AFL, ANA, the Australian Women's National League, and the Hardwood Millers' Association mounted numerous deputations to the minister to prevent the proposed excisions. The metropolitan press, led by the Argus, Australasian, and the Age thundered at the scheme and the lack of due process. The deputations pointed to earlier futile attempts at farming in the area and suggested some forests were best left unsettled; the revival of the proposition that forests influenced climate was particularly notable during this dispute. The Millers pointed to the substantial losses in employment, income and royalties that the loss of a sustainable forest industry would cause, but they sided with the FCV's rejection of some conservationists' views that all of the Otway's farmlands should be reafforested. The Millers were later joined in the agitation by the Geelong Timber Merchants' Association who feared that forest clearance might flood the local market with Otway's timber.

In June 1925, the government finally rejected local demands for land, and shelved the scheme in the face of so much opposition. But the Country Party and its supporters did achieve some major outcomes over the next few years: the resignation of FCV Chairman Owen Jones, who later bitterly attacked parliament's neglect of forestry, the reinstatement of statutory exchanges of land between the Lands and Forests departments especially under the 1927 Forests Act (dubbed the 'Deforestation Act' by conservationists), a weakening of fire controls directed at graziers, an expansion of sawmill concession areas, and with the support of the powerful Municipal Association a return of control of

32 Stephen M. Legg, 'Arcadia or Abandonment - The Evolution of the Rural Landscape in South Gippsland, 1870-1947' (MA diss., Monash University, 1984). 
'roadside timber' to local councils. ${ }^{33}$ Political agitation over settlement expansion in the Otway Ranges and Beech Forest continued over the ensuing decades, but the rationalisation of land settlement in Victoria from the late 1930s and growing acceptance of the critical role in water supply of forested watersheds meant that only minor encroachment occurred.

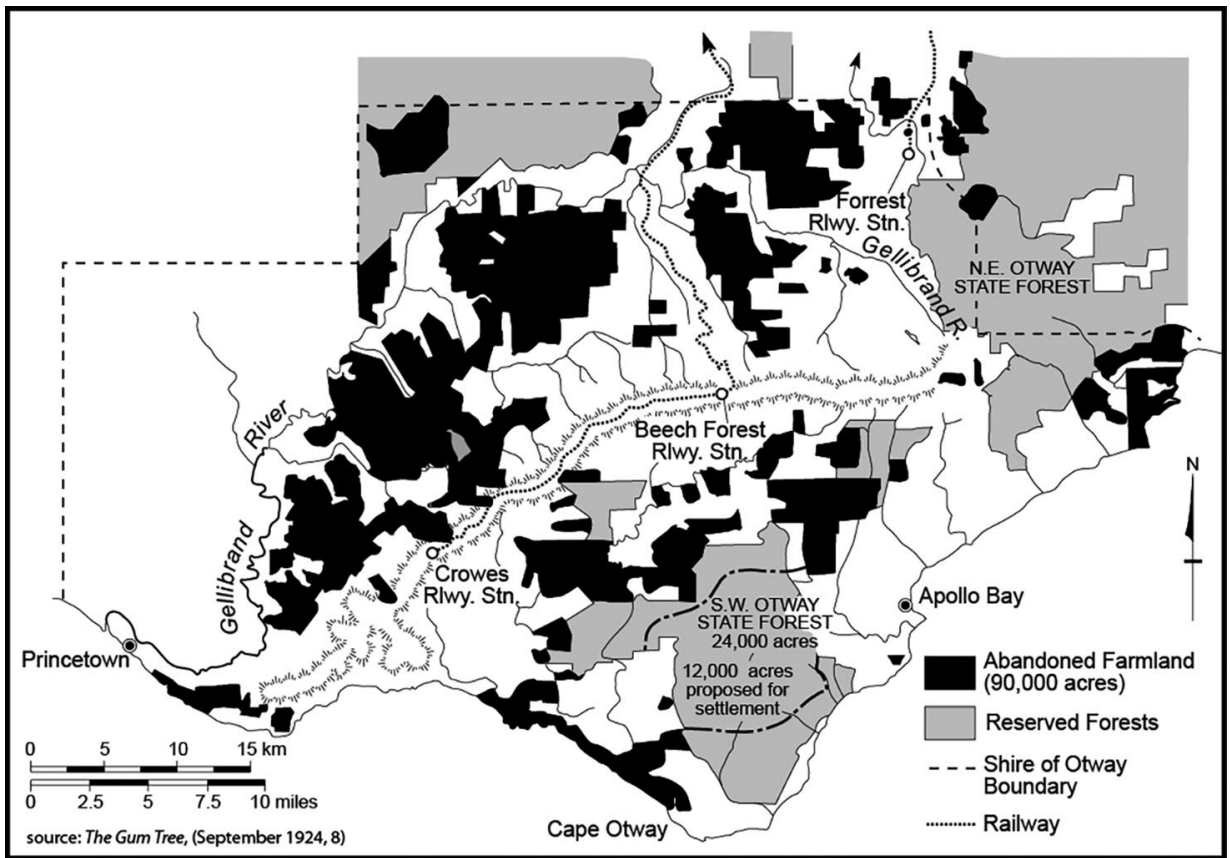

Map 2: Otway Forest dispute, 1923.

Source: The Gum Tree (Vol. 8, No. 31, September 1924, 8).

Victoria's forest disputes from the 1920s were increasingly involved in conflict over control of Victoria's watersheds (Map 3). A major component of this was ongoing tension between the FCV and the leading urban water supply manager, the Melbourne Metropolitan Board of Works (MMBW), over the latter's closure of the catchment forests from 1891, and the FCV's insistence that judicious logging, as successfully practised in other countries, would not interfere with water

33 Local disputes over roadside trees were generally managed by municipal councils. Conflict arose between ratepayers, the councils and Victorian Government over shading and water logging of road surfaces, damage to fencing, access to timber and pasture, and use of strip plantations (the AFL and ANA consistently campaigned for roadside plantations). Control temporarily swung to the FCV in the 1920s, but it was shortlived due to municipal pressure. Newspaper coverage and municipal council minutes show that 'roadside timber' was one of the most persistent and frequent issues with which the public engaged with the matter of trees in public space throughout the study period. 
supplies. ${ }^{34}$ While conservation groups sided with the MMBW, timber interests and local municipalities near the catchments lobbied to throw the catchments open for development lest they 'degrade to a worthless scrub of overmature, decaying trees' ${ }^{35}$ Growing concerns with upland erosion, fire prevention, and irrigation water supply heightened interest at this time. ${ }^{36}$ Timber interests had some limited success lobbying to gain access to the watersheds: in 1891 over the proposed diversion of the Acheron River, in 1907 over access to parts of the O'Shannassy catchment, and in both 1910 and 1915 over the Upper Yarra catchment. The mountain forests represented 35 per cent of Victoria's forest reserves and 80 per cent of the commercial timber species, as well as encompassing Melbourne's major reservoirs - O'Shannassy, Maroondah and Silvan. In 1922, the FCV pushed for the reservation for forestry purposes of 170,000 acres of mountain forests in the headwater between the Tambo and Buchan Rivers in East Gippsland, and in the Hume catchment. The following year, the MMBW responded by requesting an additional 90,000 acres of catchments, however, the Forests Minister compromised by granting the MMBW half that amount and excluding logging from within 25 miles of any weir, but throwing the other 45,000 acres open to logging to appease the timber lobby. This included almost 40,000 acres of pristine forest in the Cumberland Valley (Map 3 inset). ${ }^{37}$

34 Restrictive catchment management had been used around Yan Yean reservoir 1872-96 and in the Watts River catchment from 1885 (Legg, 'Debating Forestry', 287). See also T. Dingle and C. Rasmussen, Vital Connections: Melbourne and its Board of Works, 1891-1991 (Ringwood, Vic.: McPhee Gribble, 1991); and Peter Evans, 'The Great Wall of China: Catchment Policy and the Forests beyond the Yarra Watershed: 1850-1950', in A Forest Consciousness: Proceedings of the Sixth National Conference of the Australian Forest History Conference of the Australian Forest History Society, ed. M. Calver (Rotterdam: Millpress Science Publishers, 2005).

35 Forests Commission of Victoria-Annual Report, 1925, Victorian Parliamentary Papers, 1925-26, vol. II, no. 6 .

36 Prominent public critics of Victoria's watershed deforestation in the first half of the twentieth century included State Rivers and Water Supply Commission Chairs Elwood Mead (a co-founder of the AFL) and Sir Ronald East, FNCV member and SRSWC engineer Alfred Kenyon, and agricultural scientist Dr G. L. Wood. 37 Legg, 'Debating Forestry', 286-92. 


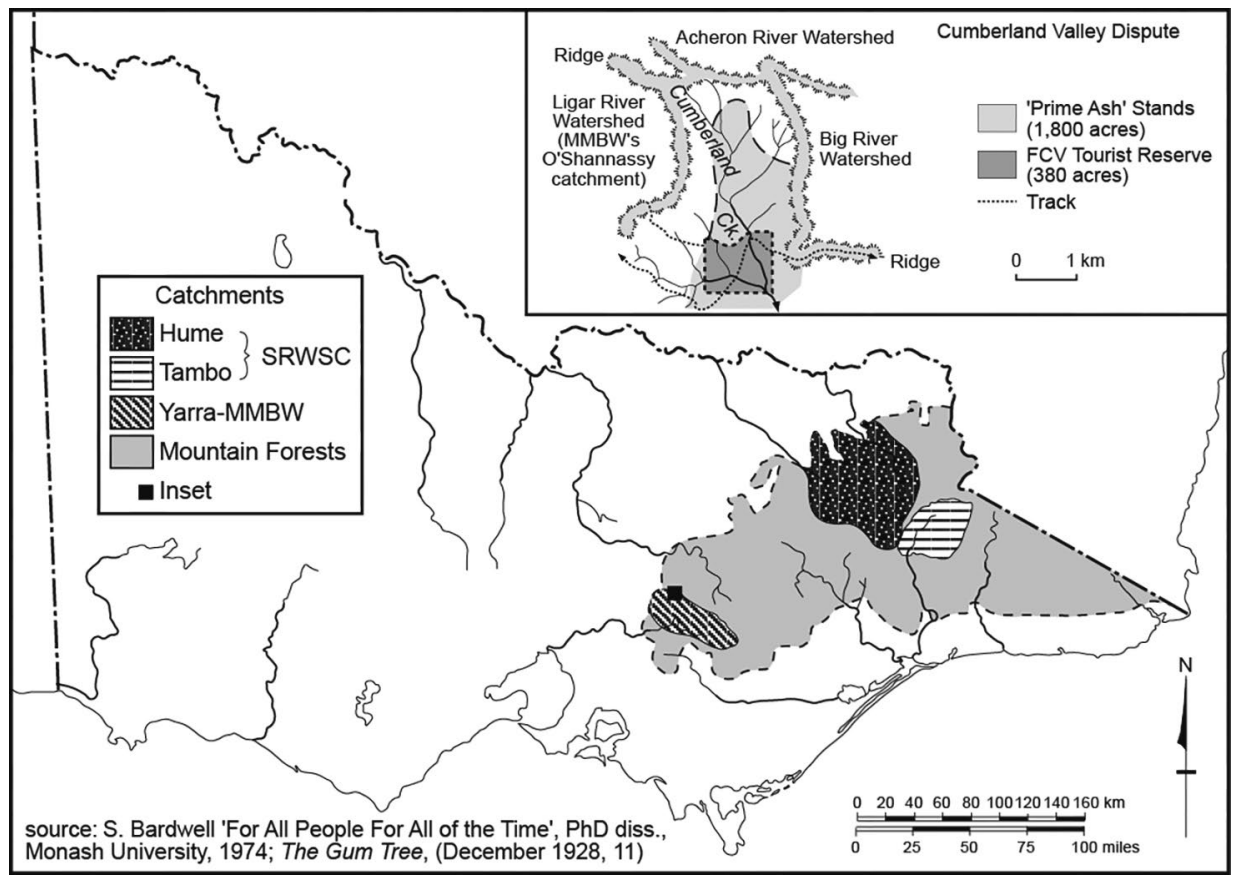

Map 3: Victoria's major forested catchments.

Source: S. Bardwell 'For All People For All of the Time', PhD diss., Monash University, 1974; The Gum Tree, (Vol. 12, No. 48, September 1924, 11).

\section{The Cumberland Valley dispute, 1923-43}

The magnificent stands of Mountain Ash at the head of the Cumberland Valley near Marysville had already gained an international reputation as the tallest grove of hardwoods in the world and a pristine beauty spot. But in silvicultural terms, according to the FCV, the trees were fast approaching their optimum commercial age and would soon 'go to waste' if allowed to become 'senescent'. The implicit notion that forests needed human intervention lest they decay or 'rot' aligned with modern forestry economics versions of opportunity cost and declining marginal returns. The idea of decay had also been regularly used by earlier Lands and Agriculture ministers to justify forest clearance and even by some of the leaders of the AFL keen on maximising forest utilisation. It was already a source of division among 'conservationists' and 'preservationists'. The Forests Minister's insistence that 'scientific forestry' would ensure that no damage was done to the beauty spot and that it was the Cumberland Falls not the trees that attracted tourists merely inflamed the situation. The agitation was initiated by a well-crafted press campaign by the Marysville Tourist Board that was soon taken up by the Melbourne newspapers, and was immediately 
supported not only by the FNCV but also by the AFL and ANA. Intervention by the influential Town and Country Planning Association (TCPA) led by eminent conservationist Charles Barrett soon followed, and a series of well-attended public meetings and deputations were held over the next few years. Prominent individuals such as painter Arthur Streeton noted the 'endless beauty of the green and living forest' and pleaded 'on behalf of all Australian artists' against the 'proposed vandalism'. ${ }^{38}$ Forests Minister H. F. Richardson made minor extensions to the planned reserve, and promised a square mile reservation as a Soldiers' Memorial in 1929. The concessions could not placate the agitators, especially those in the FNCV and the TCPA who, unsuccessfully, called for the area to be declared a National Park.

The dispute dragged on for more than 20 years; the successive Forests ministers never lost sight of the opportunities for large royalties from the logging, and always resisted attempts at permanent reservation by Order in Council, which would make forest reserves safe from ministerial whim. Strong protests were again made in 1929 by 16 major and numerous minor organisations. ${ }^{39}$ Mounting demands from neighbouring Warburton sawmillers to access the nearby forests added to the difficulties. The resurgence of gold-mining during the Great Depression saw the Cumberland groves threatened by water diversions from the Cumberland Creek for mining purposes and this set off a new round of agitation in 1934. The following year Barrett's TCPA vigorously renewed its campaign to establish the area as a National Park but little was achieved despite the FCV Chairman's insistence that the area would be preserved for all time. A few months later, agitation for logging was renewed by the Hardwood Millers' Association and listened to sympathetically by the new Minister of Forests. The AFL renewed its campaign in 1935, as part of its broader push to preserve the watershed forests. The campaigns continued over the next four years and the area, by then claimed to be Victoria's most popular tourist spot, only narrowly escaped destruction by the catastrophic Black Friday bushfires in January 1939. The Cumberland Valley forest was temporarily reprieved by timber supply from the enormous fire-killed timber salvage operations elsewhere that ensued through the war years. Nevertheless, parliament again entertained

\footnotetext{
38 Argus, 16 November 1928.

39 These included the FNCV, ANA, TCPA, AFL, Royal Society of Victoria, Historical Society of Victoria, Returned Soldiers' League, Royal Australian Ornithological Union, Bird Observers' Club, Seedsmen and Nurserymen's Association, Tree Planters' Association, Australian Wattle League, Melbourne Walking and Touring Clubs, Royal Automobile Club of Victoria, and Marysville and District Progress Association (Argus, 24 January 1929).
} 
plans to log the area in 1948 to relieve the timber shortages during the postwar housing boom. ${ }^{40}$ Unfortunately, most of the remaining 'big trees' were destroyed by storms over the next 30 years. ${ }^{41}$

\section{Diversifying Values, 1936-65}

The main legacy of the 1928 Empire Forestry Conference, that brought delegates to the Cumberland Valley, were discussions about the future establishment of a paper industry based on the novel utilisation of pulp from native eucalypt forests. Paper shortages had been canvassed in the Victorian press since 1909 and wood-based manufacture had been debated in various forms from 1916 with plans for pulping future spruce and pine plantations in Victoria's high country. Technological advances in pulping eucalypts in the 1920s and 1930s were a foundation for the Victorian Government's 1936 special legislation covering an agreement between the FCV for native timber supplies to Australian Paper Manufacturers (APM) for their new mill that became operational from 1940 at Maryvale in Gippsland. This was the centrepiece of a new age of industrial forestry in the state, although there had been earlier attempts by the Forests department and later FCV to benefit from associations with big companies. They brought economies of large scale, security of long tenure, and expanded income to reduce reliance on government financial votes and loans. ${ }^{42}$ With the FCV's primary goal of ensuring efficient forest utilisation, the simpler negotiations with only a few large firms were preferred.$^{43}$ The Great Depression put paid to 1920s plans to resettle the farmland abandoned in Victoria's semiarid Mallee and the densely forested mountainous lands. Minister of Lands and Forests Albert Lind's radical new settlement policy of 1939 finally moved the state away from marginal settlement..$^{44}$ By 1940, the long history of encroachment on

40 The role of lobbyists engaging competing 'visiting experts' is notable. In 1928 delegates from the Empire Forestry Conference in Hobart were invited to the Cumberland Valley, the pro-conservation Argus proudly publishing Empire Forestry Commission Chairman Lord Clinton's remark about the trees that 'to cut them down would be a tragedy. They should be allowed to remain for all time as one of nature's monuments' (8 November 1928). In contrast, in 1948 MLA W. H. Everard's statement in parliament that visiting 'English forest expert' Lord Robinson was 'astonished that such magnificent timber be allowed to go to waste' was published in the pro-development local newspaper the Healesville Guardian (4 December 1948).

41 G. Munro, 'Cumberland Scenic Reserve', in Secrets of the Forest: Discovering History in Melbourne's Ash Range, ed. T. Griffiths (St Leonards, NSW: Allen \& Unwin, 1992), 190-4.

42 Special legislation within the study period included the 1936 Woodpulp Agreement Act with Australian Paper Manufacturers Ltd, 1949 Forestry Pulp and Paper Company's Afforestation Contracts Act, Masonite Agreement Act 1956, and Forest (Pulpwood Agreement Act) 1959 with Commonwealth Sugar Refineries. Three more similar acts governing pulpwood and softwood supply were made in the 1960s.

43 Large companies dealt with by forest management in Victoria in the early twentieth century include the Australian Seasoned Timber Co. at Wandong, Cuming, Smith and Co.'s Wood Distillation Works and The Victorian Powell Wood Process Co. Ltd both at Powelltown, and the Goodwood Timber and Tramway Co. at Darriman.

44 The Royal Commissions into Soldier Settlement 1925 and Closer Settlement 1933, the decision to reafforest abandoned farmland for pulpwood supplies after 1936 and Lind's 1939 New Settlement policy were evidence of a more rational approach to settlement ratified by the 1943 Commonwealth Post-war Reconstruction Committee (Legg 'Arcadia or Abandonment', 403). 
forested lands was at last ended, and plans were being considered to transform the geography of sawmilling as recommended by the scathing report of the Royal Commission into the 1939 fires. ${ }^{45}$

The January 1939 bushfires and their aftermath are rightly regarded as a turning point in Victoria's forest history, but two factors are often forgotten. First, critical responses to the ensuing Royal Commission were delayed for up to five years, and second, calls for a radical change in policy approaches had already occurred two years earlier when the ANA began its major new coordinated campaign on interdependent forestry, water, and soil management. Convened by the ANA and supported by both the Victorian and Commonwealth governments, the 29 July 1937 soil erosion conference at the Melbourne Town Hall was unprecedented in the number, representation, authority and seniority of its attendees. ${ }^{46}$ This was soon followed by a joint deputation to parliament demanding a new regime of land management.

Only a few weeks after the 1939 fires, the ANA's 'Future of Forests' campaign was expanded with support from 77 other organisations. The group called for unified control of the forests, with the now embittered AFL chair Russell Grimwade lamenting the 'hopeless situation' in which despite considerable expenditure 'the government had utterly failed to safeguard the forests' ${ }^{47}$ Expert guests lectured to many of the local ANA branches through the early 1940s on the new policy of 'Forests, Soil and Water'. But a much larger public education campaign was envisaged integrating earlier advances from the 1920s in school forestry and 'forest conscience' campaigns with a massive new public education strategy. In 1944, the Save the Forests Campaign largely usurped the outmoded AFL, which lingered under the tireless Hardy's presidency until at least 1953. Among the stimuli for radical change were the spectre of the catastrophic 1939 fires and dire predictions for the 1943-44 fire season, wartime timber shortages, postwar reconstruction schemes, and especially demands for a more holistic landscape management approach. The change also reflected the plans for industrial forestry, especially given the prominent role of business leaders. These included leading AFL member industrialist and philanthropist Russell Grimwade who

45 On the end of the era of settlement: see Doolan 'Institutional Continuity', 32-5. On the changing geography of sawmilling: see Stephen M. Legg, 'The Location of the Log-Sawmilling Industry in Victoria, 1939-1977' (MA Prelim. diss., Monash University, 1977).

46 The resolutions to establish a nationwide campaign against soil erosion were moved by ANA president J. W. Marrows and supported by leaders from the forest products industry (APM chair Sir Herbert Gepp and AFL president Russell Grimwade), forest management (FCV Chair A. V. Galbraith and Commonwealth Forestry Bureau's H. R. Gray), water management (SRWSC chair L. R. East), agriculture (Dean of Agriculture Prof. S. M. Wadham and Victorian Director of Agriculture H. A. Mullett) and education (Victorian Director of Education J. A. Seitz and Teachers' Union president C. A. Jordan). The biologist F. N. Ratcliffe represented the Commonwealth Scientific and Industrial Research organisation, and Melbourne University Chancellor and prominent conservationist Sir James Barrett seconded the motions (Argus, 30 July 1937).

$47 \quad$ Argus, 3 June 1939. 
had championed 'scientific forestry' for 40 years from 1916 and APM Managing Director Sir Herbert Gepp who had been instrumental in Federal postwar reconstruction plans, and whose impassioned campaigns to prevent forest fire and ensure sustainable timber supplies were in part aligned with APM's needs. Both men had promoted the interdependence of forests, water and soil since at least 1937, and the term became popularised by Stretton's notion of an 'inseparable trinity' in the 1946 Royal Commission into Forest Grazing.

The 1944 Save the Forests Campaign, and its successor from 1952 the Natural Resources Conservation League (NRCL) maintained a strongly utilitarian stance (see Figure 3). ${ }^{48}$ Both groups received wide-ranging support from the government, including a one-off grant to the campaign in 1947 and annual funding of the League by the FCV. There was also a substantial increase in forestry funding after the 1939 fires. ${ }^{49}$ Collectively, the campaign and the NRCL included representatives from 50 organisations, including Victoria's municipalities, all of the major conservation groups as well as most of their traditional enemies, and a total nominal membership of 100,000 across the state (thanks largely to the ANA), with district committees in 28 provincial centres and an emphasis on community involvement. ${ }^{50}$ Financial and legal support was also forthcoming from APM, with the potential conflict of interests occasionally surfacing within, but contained by, the campaign's executive. The decision to decentralise support for forest conservation into rural communities was a particularly important departure from the earlier metropolitan bias of the AFL (and to some extent the Victorian National Parks Association) and was to be a hallmark of the NRCL until the mid-1990s. This was enhanced by the NRCL nurseries' supply of lowcost native trees to its farm and municipal members. From 1944, the League established community forests, adding a further dimension to the widespread Victorian Education Department's School Endowment Scheme plantations that had been developed from the 1920s. The NRCL also maintained close links with the government through an executive who worked with natural resource departments and a succession of retired senior public servants who led the League. ${ }^{51}$ The NRCL generally avoided overt political agitation-although it was instrumental in the formation of the Conservation Council of Victoria in 1970, and some of its directors, such as George Thompson (1962-72), were highly effective conservation activists networking behind the scenes.

\footnotetext{
48 Poster painted by FCV forester Harry Sennett, who trained under renowned landscape artist Frederick McCubbin.

49 In his public lecture on forestry, FCV forester H. B. Ingle noted that 'following the Royal Commission on the 1939 bush fires, money was almost unlimited for essential purposes'. Camperdown Chronicle, 16 June 1950. 50 Libby Robin, Building a Forest Conscience: An Historical Portrait of the Natural Resources Conservation League of Victoria (NRCL) (Springvale South, Vic.: Natural Resources Conservation League, 1990).

51 These included retired chairs of the Victorian Soil Conservation Authority (George Thompson), Vermin and Noxious Weeds Board (Geoff Douglas) and Forests Commission (Dr Ron Grose).
} 


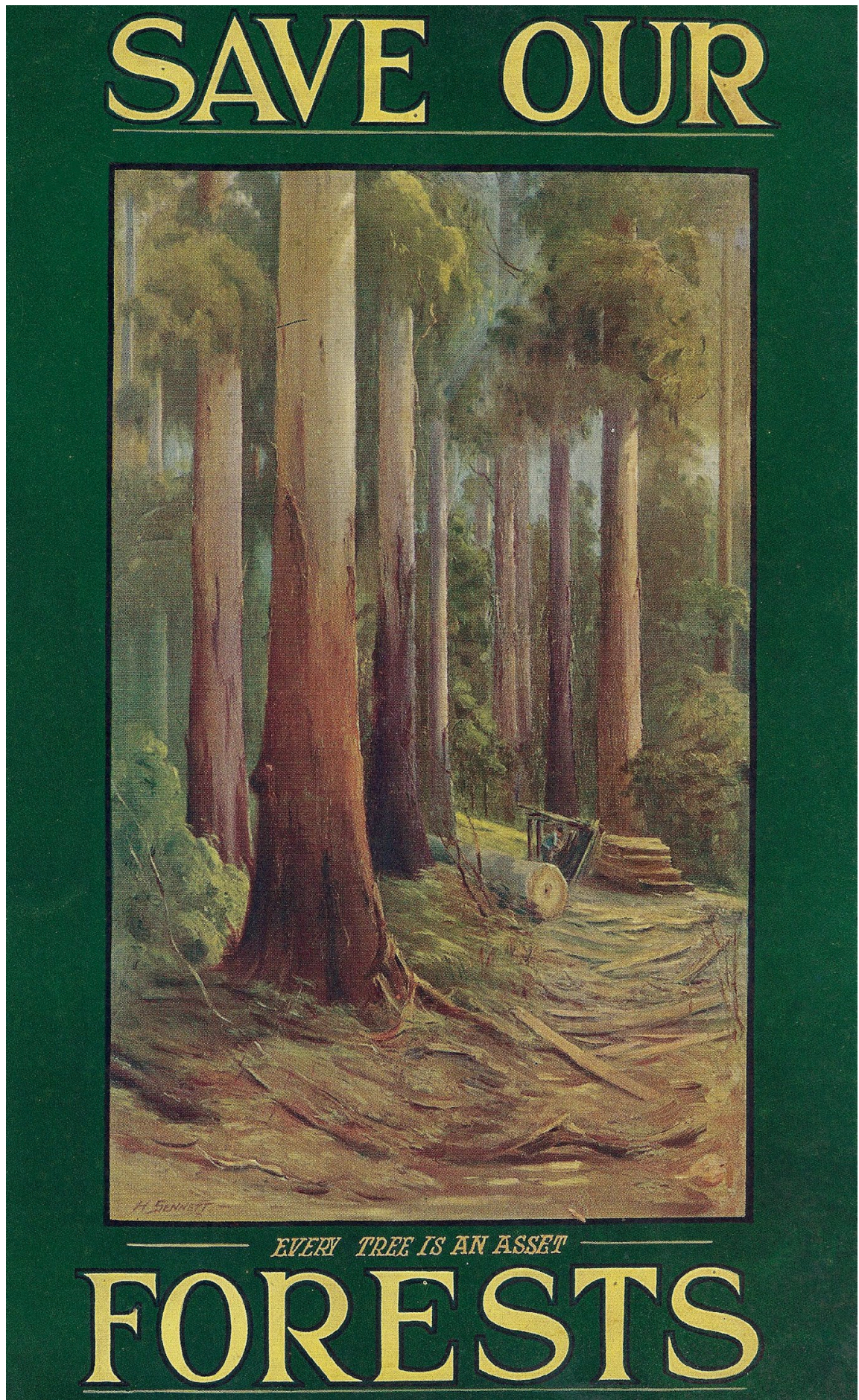

Figure 3: Save the Forests poster, FCV 1940s.

Source: Poster painted by Harry J. Sennett, lent with kind permission to the author by the artist's family. 
Political instability in the late 1940s and early 1950s saw successive Victorian parliaments postpone conservation initiatives. The newly formed Save the Dandenongs League 1950, Wildflower Preservation Society 1951, and Victorian National Parks Association 1952, reacted against wartime neglect of reserves and the postwar ethos of development, especially targeting the 1955 election. Although an independent National Parks Authority was not forthcoming until 1956, the 1950s was a period of significant but hitherto unrecognised progress in institutional development for conservation in Victoria, even under deeply conservative governments. ${ }^{52}$ During a period in which the Victorian Government updated all of its major statutes, and thanks largely to lobbying through the NRCL, the 1958 Forests Act was passed. This Act further entrenched the modern era of industrial forestry, and although little recognised at the time arguably set the scene for later polarisation of forest interests. Although some conservationists opposed aspects of forestry during the era of unprecedented economic growth in the 1950 s, the disputes were relatively minor. ${ }^{53}$

In the late 1950s, there was a remarkable groundswell of interest in natural history and conservation in general. Between 1959 and 1960, the FCNV saw the circulation of its journal The Victorian Naturalist double to 1,200 copies and membership increase from 491 to 851 . The number of conservation organisations affiliated with the FCNV increased from 16 to 23 in 1960 alone (including the Landscape Preservation Council), and there were rising sales of natural history books, as well as increasing membership of other conservation organisations including the NRCL. Across the state there were significant increases in National Park visits. ${ }^{54}$ Beginning with some limited involvement with forest reserves for specific conservation purposes such as co-management with local authorities in Sherbrooke Forest with its renowned lyrebird population and in the Lower Glenelg Forest Reserve, the FCV began to significantly increase its engagement with the public over recreation and conservation issues. ${ }^{55}$ The rising interest in alpine recreation, including skiing and bushwalking, was a factor here. Bushwalking clubs in particular had been prominent advocates for national parks in the 1930s and 1940s. Although some academic staff and students had periodically agitated on environmental issues since the 1880s,

52 See the conservation initiatives of ministers Henry Bolte and Bill Borthwick in Doolan, 'Institutional Continuity', chap. 4.

53 Occasional letters to editors during the 1950s related to threats to the Otways from a plan to establish a pulp mill, the extension of exotic plantations, and the expansion of logging in the mountain forests.

54 The Victorian Naturalist 79, no. 2 (June 1962): 31.

55 Compared to the 1920-59 average of correspondence per year in the FCV files dealing with conservation, there was a six-fold increase between 1960 and 1966 (FCV correspondence files, series 11563, Public Record Office Victoria, Melbourne). 
Melbourne's universities played an increasingly radical role from the 1960 s. $^{56}$ The tremendous increase in environmental concern across the community contributed to the formation of the Australian Conservation Foundation in 1964. The radicalisation of conservation groups that began a few years later was marked locally by the successful 1969-72 campaign to save Victoria's Little Desert from clearance for settlement and was consolidated by the campaign to establish an Alpine National Park. ${ }^{57}$ It is likely that future research will reveal that the roots of the dissent that surfaced so overtly during the late 1960s owed more than is currently realised to the diversification of interests from at least the 1950s. And although there was a gradual increase in wildlife conservation and recreation throughout the 1880s, 1920s, and 1950s, the overwhelming priority in most of the earlier conservation campaigns over the contested spaces described above was on sustaining timber and water flows. As long as virgin forests remained to fuel forest industry expansion, the increasing inability of traditional forest institutions to deal with all of the competing demands through conventional multiple-use and sustained-yield forestry policies remained hidden.

\section{Conclusion}

The long political struggle before the 1940s to secure the public forests from alienation and degradation provided a firm foundation from which there was a major expansion of modern intensive, and increasingly export-oriented, forest-based industries from the 1950s. Ironically, it was less than 20 years before mainstream forest conservationists began agitating against the industrial forestry regime that had partly developed out of, and been sanctioned under, some of the earlier struggles - described above - that had attempted to ensure forest survival through enhanced forest product values. Led by a new generation of conservationists, a significant ideological shift occurred under this new 'environmentalist' discourse, especially from the late 1960s.

A pervasive non-utilitarian stance emerged with a much greater emphasis on biodiversity, a global or perhaps 'planetary' perspective, greater polarisation of urban and rural values over natural resource management, and a growing distrust of 'big business'. This was accompanied by a powerful critique

56 Between the 1880s and 1950s these included Melbourne University scientists such as McCoy, Spencer, Ewart, Wadham, Laver, Skeats, Morris, and Green, and both Grimwade and Barrett as Chancellors, as well as student outdoor recreational groups and subject associations.

57 Libby Robin, Defending the Little Desert: The Rise of Ecological Consciousness in Australia (Melbourne: Melbourne University Press, 1998); Joseph M. Powell, An Historical Geography of Modern Australia (Melbourne: Cambridge University Press, 1988); Dick Johnson, The Alps at the Crossroads: The Quest for an Alpine National Park in Victoria (Melbourne: Victorian National Parks Association, 1974). 
aimed squarely at the FCV, which had earlier been generally perceived as an independent champion of conservation, except on those occasions, such as in the Cumberland Valley, where preservation interfered with 'progressive' forestry. These changes marked the end of what has been dubbed the 'first wave' of an Australian environmental movement with its utilitarian emphasis on conservation. ${ }^{58}$ Arguably, however, there were two waves, the first before the late 1930s dominated by the threat of agricultural clearance and a reliance on timber imports, and with most conservationists accepting that better utilisation of forest products through 'intensification' could give forests a higher value than the land on which they grew or the imports with which they competed. With the forests effectively secured, a second wave gained momentum between 1937 and 1944, and the 1950s and 1960s brought hope of a new alignment of government with conservation, and forest-based industry capital with labour. The postwar era saw the expansion of both community-based and industrial forestry and a proliferation of forest values within which intensification and forestry itself became sharply challenged, especially over the increasingly evident unsustainability of native forests despite over a century of management under scientific forestry systems. With the many threats to the forests that had so riled the early conservationists before the 1950s now long forgotten, the inevitable ecological transformation wrought by forestry became the environmentalists' new battleground. Victoria's utilitarian natural resource management policies and the highly specialised, professional, public institutions that implemented them in the fields of forest, soil, water and even National Parks were finally dismantled in a wave of massive reforms from the early 1980s. ${ }^{59}$

The 'forest wars' of recent years may reflect additional environmentalist contexts and concerns but they were neither the only nor the definitive environmental battles in a long and rich history of struggle. Many of the early campaigns were organised by non-government activist groups, but it would be misleading to ignore the critical role of the many conservation-minded bureaucrats and politicians who also worked tirelessly to save the forests. And while the cases of political agitation described above were largely confined to overt public practices, no doubt some lobby groups also had greater covert influence than others in dealing with governments. From the 1860s, there was a remarkably consistent use of techniques employed by both lobbyists and governments, but no single group championed the conservationist cause and no narrow set of values drove it. The ranks of Victoria's early forest conservationists spanned an enormous spectrum from both inside and outside the establishment.

58 Drew Hutton and Libby Connors, A History of the Australian Environment Movement (Melbourne: Cambridge University Press, 1999).

59 Doolan, 'Institutional Continuity', chaps 5 and 6. 
This text is taken from International Review of Environmental History, Volume 2, 2016, edited by James Beattie, published 2016 by ANU Press, The Australian National University, Canberra, Australia. 